\title{
PENINGKATAN PRODUKTIVITAS PETANI LAHAN KERING MELALUI OPTIMALISASI PENERAPAN SISTEM USAHATANI EKOLOGIS TERPADU DI DESA AKAR-AKAR KABUPATEN LOMBOK UTARA
}

\author{
Increased Productivity of Dry Land Farmers Through Optimized \\ Application of Integrated Ecological Farming Systems \\ in Akar-akar Village, North Lombok
}

\author{
I Ketut Ngawit ${ }^{*}$ Ni Made Laksmi Ernawati, dan Nihla Farida \\ *Program Studi Agroekoteknologi, Fakultas Pertanian Universitas Mataram \\ Jalan Majapahit Nomor 62 Kota Mataram Provinsi NTB \\ ${ }^{*}$ Alamat korespondensi: ngawit@unram.ac.id
}

(Tanggal Submission: 12 Mei 2020, Tanggal Accepted: 30 Agustus 2020)

\begin{abstract}
ABSTRAK
Permasalahan utama yang dihadapi oleh petani di wilayah pengembangan lahan kering Lombok Utara antara lain, produktivitas tanah dan kemampuan kewirausahaan petani rendah, serta pemanfaatan sistem hubungan timbal balik antara tanaman dengan ternak (Crop and life stock animals relation) masih kurang.Tujuan kegiatan pengabdian kepada masyarakat ini adalah : Meningkatkan pengetahuan dan keterampilan petani dalam mengelola lahan usahataninya; Diperoleh model produksi berupa sistem usatani ekologis terpadu; dan Diproduksi pakan ternak awetan berupa hay dan silase. Tindakan yang telah dilakukan untuk mengatasi masalah tersebut adalah: Pelatihan dan kaji tindak berupa demplot dan pendampingan secara langsung tim pelaksana kegiatan terhadap petani tentang aplikasi model rancang bangun usahatani ekologis terpadu, pendampingan pengolahan gulma, produk hijauan (forage), dan limbah pertanian menjadi silase dan hay. Berdasarkan hasil evaluasi seluruh aktivitas kegiatan dan analisis secara ekonomi model usaha tani yang diterapkan diperoleh beberapa luaran pokok yaitu : Petani sasaran mengikuti kegiatan pelatihan dan pelaksanaan demplot sangat antusias. Model masukan teknologi yang diintroduksikan memberikan hasil yang cukup tinggi. Keuntungan yang lebih banyak diperoleh dengan penerapan model usahatani ekologis terpadu ini karena pemeliharaan tanaman lebih mudah, efisien pengairan dan petani selalu dapat menyediakan komoditi sayuran setiap hari, sehingga lebih mudah pemasarannya. Keberhasilan peserta dalam pengolahan gulma dan limbah pertanian menjadi Hay dan Silase selain dapat memberikan nilai tambah secara ekonomi juga secara agronomis sangat menguntungkan karena dapat menjaga tanaman dari gangguan gulma, serta kesuburan tanah untuk usahatani yang berkelanjutan.
\end{abstract}

Kata kunci: produktivitas petani, usahatani ekologis terpadu, lahan kering, gulma.

\section{PENDAHULUAN}

Lahan kritis di Nusa Tenggara Barat (NTB), mencapai luas 2.176.600 ha dengan topografi bergelombang dan berbukit-bukit, sementara lahan topografi landai lebih sempit, sehingga lahan kritis sangat berpotensi untuk menjadi meluas dari tahun ke tahaun (BPS, 2001). Khusus di Pulau Lombok luas lahan kritis lebih banayak terdapat di wilayah Lombok Utara dibandingkan dengan di wilayah Pulau Lombok lainnya. Selain karena wilayah pegunungan dan perbukitannya yang lebih 
banyak, juga memeliki iklim yang lebih kering serta kondisi tanah yang porous (Kusnarta, 1996). Akibatnya jika terjadi salah pengelolaan, lahan kritis di daerah ini akan terus bertambah. Permasalahan tersebut semakin diperparah karena adanya beberapa kendala seperti, terbatasnya air permukaan, rendahnya kestabilan agregasi lapisan olah tanah, rendahnya kadar bahan organik, kurangnya potensi sumber daya manusia dan masih rendahnya kemampuan permodalan petani pengelolanya (Kusnarta et al., 1998; Ngawit, 2002; Ngawit et al., 2008). Dampak langsung dari semakin kritisnya lahan akibat mengalami erosi adalah terjadinya suatu daerah yang secara bertahap akan menjadi tandus, dan sebagai konsekuensinya penduduk yang tinggal di sekitarnya akan menjadi miskin (Dickey,1984).

Upaya pencegahan meluasnya wilayah lahan kritis dan penduduk miskin di wilayah tersebut, diperlukan tindakan pembinaan yang berkelanjutan dan sinambung mengenai cara pengelolaan lahan, bagi penduduk sekitar yang berprofesi sebagai petani. Pengelolaan lahan yang tepat dan terencana melalaui penerepan teknologi rancang bangun model pertanian ekoligis terpadu. Titik sentra pada pertanian ekologis terpadu adalah rancang bangun teknologi dan pengolahan masukan secara holistik (multidiscipline approach) pada tanah, sebagai blue print umtuk mencapai keluaran yang diinginkan.

Salah satu bentuk usahatani ekologis terpadu yang telah diterapkan oleh beberapa petani di wilayah Lombok Utara, adalah sistem budidaya lorong (Allay cropping) dengan menggunakan tanaman tahunan seperti kelapa, cokelat, lada, mangga, pisang, dan pepaya sebagai tanaman pokok, tanaman kelompok leguminosae dan rumput-ruputan sebagai tanaman pagar, dan tanaman semusim/pangan sebagai tanaman lorong. Tujuan pokok penerapan sistem usahatani ini menurut Ngawit et al. (2008), adalah mengurangi erosi dan menyuburkan tanah, meningkatkan pendapatan petani dan sekaligus meningkatkan status profesionalisme petani, investasi jangka panjang dalam bentuk usahatani perkebunan dan tanaman kehutanan, optimalisasi pemenfaatan sumberdaya alam, kelestarian lingkungan, dan pengembangan wilayah. Petani yang telah menerapkan sistem usahatani ekologis terpadu cukup potensial untuk terus berkembang karena mereka telah mampu memperluas lahan garapannya berupa lahan tegalan atau kebun beririgasi irigasi air tanah dengan fasilitas sumur bor bertenaga mesin disel. Produk unggulan yang telah diproduksi meliputi tanaman palawija, buahbuahan dan sayur-sayuran semusim, yang antara laian : kacang tanah, kacang hijau, kedelai, dan jagung. Sedangkan sayur-sayuran semusim seperti cabe rawit, cabe bersar, tomat, sawi, bayam, buncis, mentimun, pare, dan kacang panjang. Buah-buahan semusim antara laian : semangka, melon, blewah, tomat, dan mentimun. Peralatan produksi yang dimiliki antara lain: hand traktor; sprayer berbagai type; kendaraan angkutan; dan peralatan penunjang produksi lainnya. Mereka juga telah mampu mengadakan modal sendiri pada setiap pengusahaan komuditi unggulan serta mampu membayar tenaga kerja harian tetap (Ngawit et al., 2018).

Masalah pokok yang menjadi kendala dalam setiap pengusahaan komuditi unggulan pada sistem usahatani ekologis terpadu di lahan kering Lombok Utara, adalah semakin menurunnya produktivitas tanah. Penurunan produktivitas tanah ini, sejalan dengan semakin menurunnya kadar bahan organik tanah sebagai akibat sistem usahatani yang diterapkan ternyata tidak mampu menjaga keseimbangan antara masukan dengan keluaran pada tanah. Pemberian input hanya sedikit dapat mengimbangi kehilangan bahan baku yang terangkut oleh panen dan faktor alam seperti pencucian dan erosi (Ngawit et al., 2008; Ernawati et al., 2014). Selain itu masalah gulma juga masih menjadi kendala yang cukup sulit diatasi, sehingga untuk pengendaliannya pada setiap pengusahaan tanaman diperlukan biaya 20- 
$25 \%$ dari total biaya produksi (Ngawit dan Nihla Farida, 1999; Ngawit et al., 2008). Pengelolaan gulma dengan memanfaatkannya sebagai pakan ternak masih terbatas pada jenis-jenis gulma tertentu, pada waktu musim hujan dan atau pada waktu ada tanaman. Sementara pada waktu musim kemarau terjadi kelangkaan pakan ternak.

Salah satu tindakan yang tepat untuk mengatasi permasalahan tersebut adalah dengan memanfaatkan sistem hubungan timbal balik antara tanaman dengan ternak (Crop and life stock animals relation) melalui peningkatan secara konsisten populasi ternak khususnya jenis Ruminansia. Konsekuensi peningkatan populasi ternak itu, tentu harus diimbangi dengan penyediaan pakan baik kuantitas, kualitas dan kontinyuitas yang cukup. Oleh karena itu pengelolaan gulma, limbah pertanian dan produk hijauan lainnya (forage) sebagai bahan baku pakan ternak awetan seperti silase dan hay dengan memanfaatkan teknologi tepat guna, merupkan pilahan yang tepat. Dengan demikian pupuk organik juga dapat diproduksi mandiri oleh petani secara kontinyu karena bahan baku selalu tersedia dari limbah kandang ternak dan seresah in-situ tanaman. Keuntungan lain tentu pendapatan petani akan meningkat dengan semakin bertambahnya populasi ternak yang dapat dipelihara (Ernawati dan Ngawit, 2015).

Secara geografis, lahan kering di kawasan Lombok Utara kounturnya bergelombang dan berbukit-bukit sehingga sangat rawan dengan erosi. Keadaan iklim kering dengan bulan basah kurang dari 6 bulan/tahun, dan sifat curah hujan sangat eratik menyebabkan lapisan tanah selalu tererosi pada waktu musim hujan. Kenyataan tersebut diperburuk oleh karakter petani setempat yang melakukan kegiatan budidaya tanaman kurang memperhatikan keadaan lahan, seperti topografi dan kesuburan tanahnya, sehingga proses penurunan produktivitas tanah terjadi semakin cepat. Sehubungan dengan masalah tersebut, maka telah dilaksanakan program pengabdian kepada masyarakat melalui kegiatan pelatihan dan kaji tindak/demplot di desa Akarakar, Bayam, Lombok Utara. Tujuan utama yang ingin dicapai dalam kegiatan ini adalah :

1. Meningkatkan pengetahuan dan keterampilan petani dalam mengelola lahan usahataninya, baik dari segi teknologi budidaya dan management usaha, sehinga terbentuk petani berkarakter wirausahawan.

2. Diperoleh model produksi berupa sistem usatani ekologis terpadu yang berbasis konservasi lahan dan air serta berwawasan agribisnis dan berkelanjutan.

3. Dapat diproduksi pakan ternak awetan berupa hay dan silase berkualitas berdasarkan kemampuannya meningkatkan pertumbuhan ternak sapi.

\section{METODE KEGIATAN}

\section{Kerangka Pemecahan Masalah}

Metode pendekatan yang diterapkan untuk penyelesaian permasalahan dalam pengelolaan model produksi di lahan kering adalah Program Tindak Partisipatif (Participatori Action Program), yaitu tim pelaksana proyek melibatkan petani sebagai mitra usaha agribisnis sejak awal pelaksanaan sampai evaluasi proyek. Pendekatan yang dilakukan adalah dari bawah dan dari atas (Bottom-up and top down approach) dengan mamperhatikan pengetahuan, keterampilan dan kearifan para petani mitra (Hutwan Syarifuddin et al.,2016). Masing-masing model produksi yang telah diaplikasikan dengan petani mitra, merupakan unit produksi yang bersifat stimulan dan merupakan usaha tambahan dan penyempurnaan dari unit-unit usaha yang telah ada. Karena itu, petani yang dijadikan mitra uasaha adalah pengusaha kecil yang mau dan siap bekerjasama berdasarkan pola kemitraan yang saling menguntungkan.

Model produksi usahatani yang akan dikembangkan diarahkan untuk membentuk unit 
usahatani ekologis terpadu. Model tersebut diaplikasikan dalam sistem allay coping antara tanaman tahunan seperti mangga dan kelapa sebagai tanaman tegakan utama. Tanaman pisang dan pepaya baik yang belum berproduksi maupun yang telah dewasa, dijadikan sebagai tanaman tegakan bawah. Sebagai tanaman sisipan (allay) adalah tanaman semusim yang memiliki nilai ekonomi dan pangsa pasar luas seperti sayursayuran dan buah-buahan semusim. Pengusahaan tanaman ini dilakukan secara intensif dan disesuaikan dengan lingkungan serta kemampuan petani setempat, sehingga mudah dilaksanakan dan dapat mencapai sasaran teknis agronomis dan ekonomis. Jenis tanaman semusim yang diusahakan sebagai tanaman sela adalah : Cabe merah, Sawi, Bayam, Kacang Panjang, Buncis, Mentimun, Tomat, Semangka, dan Jagung manis.
Selain dari aspek teknis, model produksi usahatani ekologis terpadu yang akan diterapkan juga memperhatikan aspek ekonomi, yaitu dengan memperhitungkan potensi nilai ekonomi produk yang dihasilkan. Bila diproyeksikan tingkat produksi tanaman yang dicapai dengan skenario pesimis dan dibandingkan dengan biaya investasi dan harga jual, maka semua komuditi yang diusahakan cukup menguntungkan dan layak dikembangkan dari aspek investasi jika nilai BC-ratio lebih besar dari satu. Mekanisme kegiatan ini dilaksanakan melalui beberapa tahap yang antara lain : 1). Penetapan petani sasaran sebagai mitra; 2). Pelatihan dan penyuluhan; 3). Kegiatan kaji tindak di lapangan; 4). Pembinaan dan pendampingan; dan 5). Monitoring serta evaluasi kemajuan program, yang secara rinci tahapan-tahapan seluruh kegiatan disajikan pada Gambar 1. 


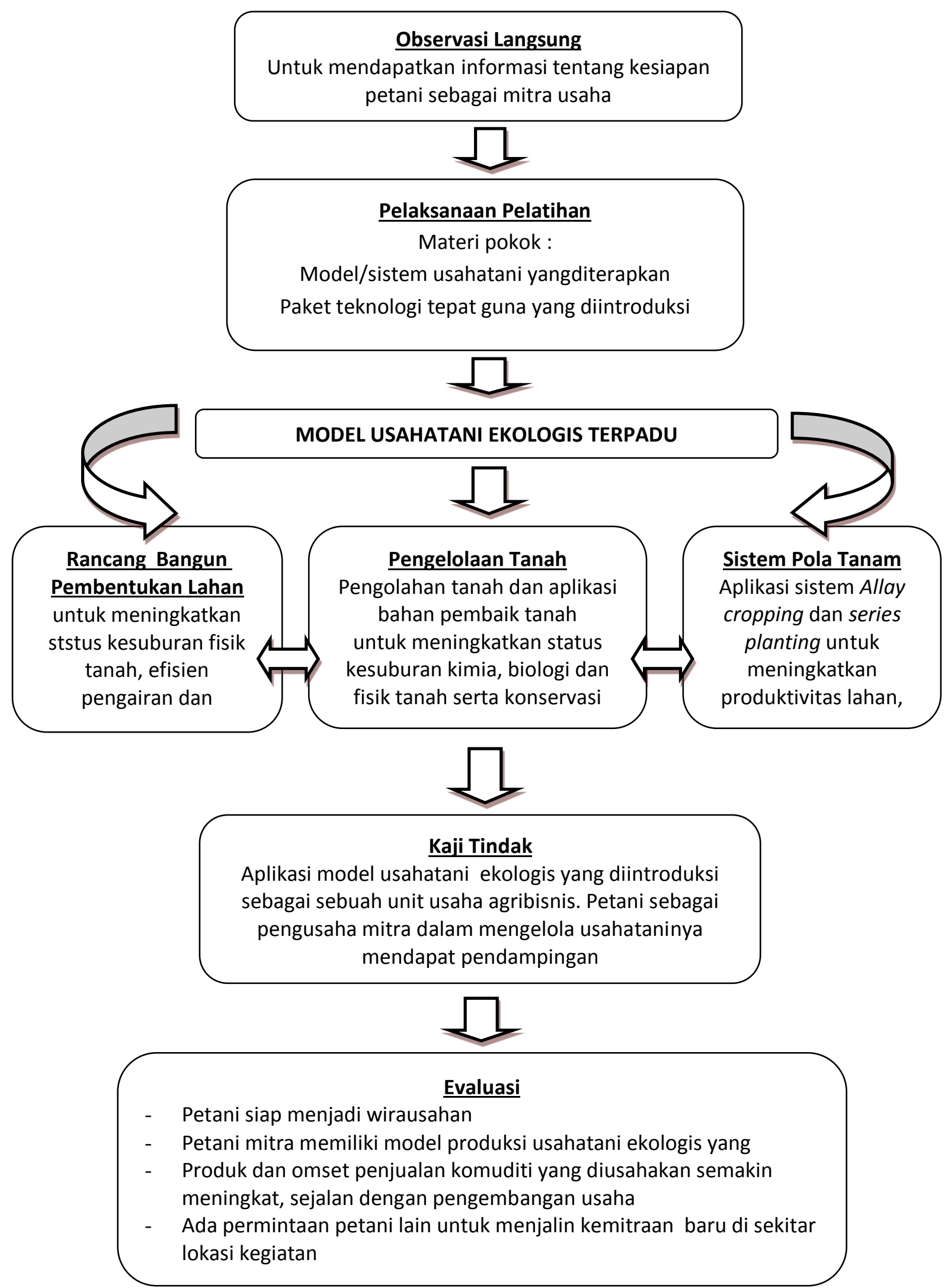

Gambar 1. Bagan Alir Kerangka Pemecahan Masalah Petani Mitra 


\section{Keterkaitan dan Evaluasi}

Usaha untuk mempertahankan keberlanjutan usahatani ini, dilakukan dengan menjalin hubungan dan kemitraan dengan pihak swasta, terutama penyalur saprodi dan pihak grosir yang siap menampung dan membeli produk sayursayuran dan buah-buahan yang dihasilkan. Guna melanjutkan kegiatan usahatani pada siklus tanam berikutnya, maka diterapkan sistem pemberian dana stimulan bergulir (revolving funds) untuk pengusahaan tanaman semusim, yang besarnya $50 \%$ dari nilai total penjualannya. Untuk kelancaran produksi dan pemasaran hasil, PT. Tanindo Subur Prima siap membantu sebagai fasilisator Technical Service.

Supaya dapat diketahui keberhasilan masing-masing model produksi yang diaplikasikan, maka dilakukan evaluasi terhadap kinerja petani mitra dan pengenbangan sistem usahatani ini yang terdiri atas beberapa tahap, yaitu :

1. Tahap pertama, keseriusan dan antusiasme petani mitra dalam mengelola usaha taninya.

2. Tahap kedua, pada akhir siklus tanam diamati beberapa parameter agronomis seperti: a). Efisiensi penggunaan air irigasi; b). Pertumbuhan dan hasil tanaman pokok dan tanaman tahunan; dan d). vegetasi penutupan tanah.

3. Sebagai indikator dari keberhasilan program ini adalah : a). Petani yang dibina telah siap menjadi wirausahawan; b). Petani mitra memiliki model produksi usahatani ekologis yang berkelanjutan berupa investasi ternak ruminansia (sapi), kebun atau tanaman tahunan dan kehutanan/kayu semakin bertambah; c). Produk dan omset penjualan komuditi yang diusahakan semakin meningkat, sejalan dengan pengembangan usaha; d). Ada permintaan petani lain untuk menjalin kemitraan baru di sekitar lokasi kegiatan.

\section{HASIL DAN PEMBAHASAN}

Pelaksanaan Kegiatan Pelatihan dan

\section{Penyuluhan}

Petani sasaran sangat antusias mengikuti semua rangkaian kegiatan pembelajaran, hal ini terbukti dari semangat kehadiran dan aktivitas mereka dalam mengajukan berbagai pertanyaan dan mengungkapkan permasalahan yang ditemuai dalam setiap kegiatan usahataninya (Gambar 2). Berdasarkan hasil diskusi dan beberapa pertanyaan yang diajukan oleh para petani peserta pelatihan maka ada beberapa kendala dan permasalahan pokok yang dihadapi oleh petani di loaksi kegiatan. Permasalahan yang dimaksud antara laian :

1. Iklim yang tidak menentu, sehingga turunnya musim hujan dan periode bulan basah semakin berkurang dan tidak menentu.

2. Periode musim hujan yang biasanya mulai Oktober/Nopember - Januari/Pebruari, pada akhir-akhir tahun ini semakin tidak menentu dan periode musim hujan lebih singkat. Akibatnya petani sulit menentukan saat tanam yang tepat dan memilih jenis komuditi yang diusahakan.

3. Petani yang wilayahnya berada pada topografi lebih tinggi, yang tidak terjangkau fasilitas sumur bor, tanaman semusim yang dapat diusahakan lebih terbatas, seperti kacang tanah, kacang hijau, kacang jongkok, kacang koro dan ubi kayu.

4. Permasalahan lainnya adalah keadaan tanah yang labil (mudah tererosi), miskin unsur hara dan bahan organik. Akibatnya dalam setiap pengusahaan tanaman dibutuhkan masukan pupuk dan obatobatan cukup tinggi agar tanaman tumbuh baik. 


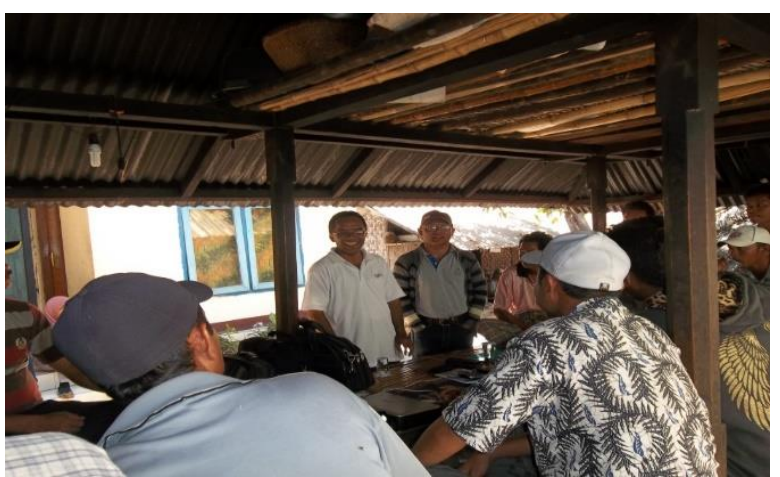

Gambar 2. Antusias petani mengikuti diskusi dan tanya jawab dalam kegiatan pelatihan di Desa Akar-akar, Keamatan Bayan, Kabupaten Lombok Utara

Selaian beberapa permasalahan tersebut di atas, pengairan juga menjadi kendala yang sangat penting dalam setiap pengusahaan tanaman di wilayah ini. Petani dapat memanfaatkan irigasi air tanah melalui fasilitas sumur bor. Berdasarkan hasil pengamatan petani melakukan penyiraman selama 5-6 jam untuk setiap hektar tanaman. Ini berarti efisien penggunaan air irigasi sangat rendah karena banyak yang meluber mengikuti aliran permukaan tanah. Sebagai contoh, pengusahaan tanaman jagung membutuhkan penyiraman sebanyak $5 \mathrm{~s} / \mathrm{d}$ 6 kali. Setiap penyiraman butuh waktu 5 jam, bila biaya penyiraman per jam Rp 50.000,- maka biaya pengairan sampai panen manjadi Rp 1.250.000,s/d Rp 1.300.000,- Jadi jelas inilah yang menjadi kendala pokok petani dalam mengelola lahan pertaniannya. Rata-rata biaya pengairan yang cukup besar terjadi pula pada pengusahaan tanaman yang berumur lebih panjang seperti cabe dan tomat. Implikasi dari umur tanaman yang demikian menyebabkan biaya pengairan lebih besar dibandingkan dengan umur tanaman yang lebih pendek seperti kacang panjang dan kacang hijau. Lama waktu pengairan pada setiap aktiviats usaha tanai dipengaruhi oleh bentuk relief permukaan tanah, sifat fisik tanah yang meliputi perkulasi, daya serap dan daya ikat tanah terhadap air, serta sifat biologi tanah terutama kandungan bahan organik tanah.

\section{Hasil Kegiatan Kaji Tindak/Demplot}

Kegiatan kaji tindak/demplot dimulai tanggal 22 Juni 2018, yang dilakukan dalam dua (2) kelompok di dua dusun, yaitu Dusun Batu Keruk dan Batu Kumbung. Penentuan kelompok ini berdasarkan keadaan lahan dan jenis tanaman allay/sisipan yang umum diusahakan oleh petani setempat. Pelaksanaan kegiatan diawali dengan pemmbentukan lahan sesuai dengan model rancang bangun yang diintroduksikan. Lahan dibentuk petak-petak seperti sawah keci dengan pengolahan tanah intensif, perbaikan pematang dan sengkedan untuk memudahkan pengairan. Selanjutnya dilakukan aplikasi bahan pembaik tanah seperti pupuk kandang dan kompos pada setiap petak yang terbentuk. Aplikasi pupuk kandang dan kompos dengan dosis 20-30 ton/ha, serta pupuk NPK dengan dosis $200 \mathrm{~kg}$ urea/ha; 100 $\mathrm{kg} \mathrm{TSP} / \mathrm{ha}$; dan $100 \mathrm{~kg} \mathrm{KCl} / \mathrm{ha}$.

Pelaksanaan kaji tindak/demplot pada kelompok I di Dusun Batu Keruk, dilakukan pada areal perkebunan dengan tanaman pokok kelapa sebagai tegakan dan pisang sebagai tanaman pagar. Di antara barisan-barisan tanaman tersebut ditanami tanaman jagung, kacang tanah dan kacang hijau sebagai tanaman sisipan (Gambar 3). Evaluasi dilakukan terhadap status kesuburan tanah pertumbuhan dan perubahan haasil tanaman kelapa dan pisang. Selain itu dilakukan pula analisis terhadap hasil tanaman semusim serta produktivitas usahatani yang diintruduksikan. Secara rinci hasil beberapa paramater yang dijadikan sebagai tolak ukur untuk mengevaluasi kegiatan disajikan pada Tabel 1.

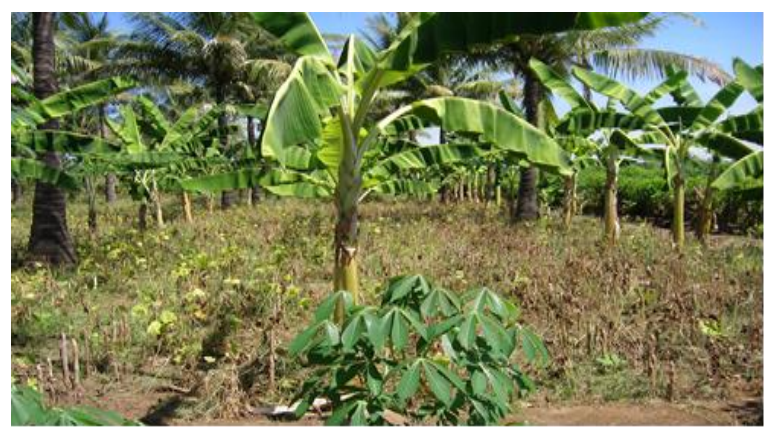


Gambar 3. Pertumbuhan tanaman pisang dan kelapa yang semakin membaik setelah penerapan model rancang bangun usahatai ekologis terpadu di Desa Akar-akar, Keamatan Bayan, Kabupaten Lombok Utara

Setelah aplikasi komponen masukan teknologi model rancang bangun usahatani ekologis terpadu, terjadi perubahan status kesuburan tanah yang lebih baik dibandingkan dengan sebelum penerapan model usahatani ini. Demikian pula terhadap pertumbuhan tanaman kelapa dan pisang. Terjadi peningkatan produksi tanaman pisang dan kelapa setelah penerapan model usahatani ini selama 6 bulan. Namun pisang peningkatan hasilnya tidak tinggi, hal ini diduga akibat adanya penyakit mati pucuk/busuk batang aktusibat infeksi fusarium terhadap batang pisang sejak masih muda sampai menjelang siap buah, sehingga buah pisang yang masih muda banyak yang rusak. Sedangkan hasil tanaman semusim seperti kacang tanah, jagung dan kacang hijau peningkatan hasilnya cukup tinggi, terutama jagung dan kacang tanah yang peningkatan hasilnya dapat mencapai rata-rata 2,54 ton untuk jagung dan 1,97 ton kacang tanah. Peningkatan hasil ini diduga erat kaitannya dengan semakin meningkatnya status kesuburan tanah karena berdasarkan hasil pengamatan dan analisis di laboratorium, tampak perubahan status kesuburan tanah setelah aplikasi model rancang bangun usahatani ekologis ini cukup tinggi terutama terhadap kandungan bahan organik tanah dan indek populasi cacing tanah. Penggunaan air menjadi lebih efisien karena pengairan untuk tanaman jagung dan kacang tanah hanya dilakukan 5 kali, dengan waktu penyiraman selama $4 \mathrm{jam} / \mathrm{ha}$. Total produksi jagung yang dapat dihasilkan 5,6 ton/ha hasil ubinan pipilan kering dan total produksi kacang tanah mencapai 2,1 ton/ha hasil ubinan (Tabel 1). Pendapatan dan laba bersih yang cukup tinggi diperoleh pada aktivitas pengusahaan tanaman kacang tanah dan jagung (Tabel 2). Selain dapat memberikan laba bersih yang tinggi, nilai BCratio pengusahaan kedua jenis tanaman tersebut juga relatif lebih tinggi dibandingkan dengan pengusahaan komuditi lainnya, yaitu untuk tanaman kacang tanah berkisar antara 2,21-3,00 dan jagung berkisar antara 2,08 $-2,47$. Ini berarti bahwa setiap penambahan satu satuan biaya produksi untuk pengusahaan tanaman kacang tanah dan jagung akan diperoleh tambahan pendapatan $2-3$ kali dari tambahan biaya produksi. Pengembalian nilai investasi (Break even poin) pengusahaan kacang tanah, tercapai pada kondisi haraga $\mathrm{Rp} 8000,-/ \mathrm{kg}$, jika produksi rata-rata per hektar mencapai, 4,5-5,0 ton/Ha. Bila produksi bisa dipertahankan mencapai rata-rata 4,5 ton/ha, maka pengembalian nilai investasi, tercapai pada kisaran harga $\mathrm{Rp} 8.000-\mathrm{Rp} 9.000 / \mathrm{kg}$. Hal yang sama tampaknya terjadi juga pada produk jagung, bahwa nilai BC-ratio yang diperoleh berkisar antara 2,0 - 2,58 dan nilai BEP juga stabil selama pengusahaan. Nilai BC-ratio yang rendah diperoleh pada tanaman kacang hijau, yaitu mendekati nuilai 1 (satu). Hal ini berarti bahwa berapapun nilai investasi untuk penambahan biaya produksi tidak diperoleh tambahan pendapatan yang berarti.

Kegiatan kaji tindak/demplot pada kelompok II di Dusun Batu Kumbung, dilaksanakan pada waktu yang bersamaan. Model rancang bangun usahatani ekologis terpadu yang diterapkan sama seperti di wilayah kelompok I (Dusun Batu Keruk), yang membedakan di sini adalah keadan lahan dan keragaman jenis tanaman semusim dan frekuensi penanaman yang dapat dilakukan sepanjang tahun karena ada fasilitas isigasi sumur bor yang lebih memadai. Demplot dilaksanakan pada perkebunan dengan tanaman pokok mangga sebagai tegakan dan pepaya sebagai tanaman pagar. Sebagai tanaman lorong kacang tanah, jagung, kacang hijau dan beberapa sayuran semusim cabe rawit, cabe merah, tomat dan kacang panjang. Evaluasi yang dilakukan sama seperti demplot di lokasi I, yaitu 
terhadap perubahan status kesuburan tanah, pertumbuhan dan hasil tanaman serta efisiensi pengairan yang dihitung berdasarkan volume air yang diberikan selama pertumbuhan tanaman terhadap hasil nyata tanaman.

Produksi cabe merah (besar) dan jagung manis tidak sesuai harapan, yaitu hasilnya sangat rendah dan hampir gagal total. Pada panen pertama hasil cukup tinggi, namun pada panen berikutnya, produksi buah cabe merah sangat merosot karena ada serangan hama lalat buah. Akibatnya terpaksa dipanen muda dengan harga pasaran sangat murah yaitu hanya $\mathrm{Rp} 2.500,-/ \mathrm{kg}$. Pemeliharaan tanaman semusim secara intensif yang diusahakan secara berseri pada lorong-lorong di antara tanaman tahunan tersebut, ternyata berimbas pula terhadap semakin membaiknya pertumbuhan dan hasil tanaman pepaya, mangga, dan kelapa. Setelah penerapan sistem usahatani ekologis terpadu dengan pola seri planting, secara fisual tampak pertumbuhan tanaman dan jumlah buah per pohon tanaman tahunan tersebut terjadi peningkatan yang cukup tinggi. Berdasarkan hasil panen pada akhir siklus kedua penerapan sistem ini, rata-rata buah pepaya yang dapat dipanen mencapai 4,8 buah/pohon/minggu, kelapa 32,5 buah/ponon/bulan, dan mangga $225,25 \mathrm{~kg} /$ pohon. Hasil rata-rata selama 6 bulan untuk kelapa 19.658 buah/ha yang semula hanya 3456 buah/ha dan pisang 2,644 ton/ha yang semula hanya 1,422 ton/ha. Peningkatan hasil mangga dan pepaya juga tinggi, yaitu yang semula hanya 2,24 ton/ha menjadi 4,84 ton/ha untuk mangga dalam satu musim, sedangkan pepaya selama 6 bulan yang semula hanya 1,48 ton/ha menjadi 2,12 ton/ha (Tabel 1.)
Pendapatan dan laba bersih cukup tinggi diperoleh pada usaha tanaman cabe rawit, kacang tanah, jagung dan kacang panjang. Nilai BC-ratio pengusahaan empat jenis tanaman tersebut juga relatif lebih tinggi dibandingkan dengan pengusahaan komuditi lainnya, yaitu untuk tanaman cabe rawit 2,58-2,90, kacang tanah berkisar antara 2,21 - 2,79; kacang panjang 2,552,60; dan jagung berkisar antara 2,21 - 2,47. Hal sebaliknya justru terjadi pada cabe merah, kacang hijau dan jaguing manis, bahwa nilai BC-ratio yang diperoleh mendekati satu (1) dan nilai BEP juga tidak stabil selama pengusahaan. Penyebab utama hal ini terjadi pada pengusahaan tomat tampaknya bukan karena masalah produksi, akan tetapi berkaitan dengan kestabilan harga (Tabel 2).

Kegiatan kaji tindak di kedua kelompok petani sasaran dilakukan pula pelatihan pengelolaan gulma, limbah pertanian dan forage lainnya sebagai pakan ternak awetan Hay dan Silase. Produk pakan ternak awetan Hay dan Silase disajikan pada Gambar 4. Hasil dari produk pakan ternak olahan tersebut dievaluasi terhadap status kandungan nutrisinya, TDN = Total Digestable Nutriens, tingkat kesukaan ternak sapi Bali, dan pengaruhnya terhadap pertumbuhan yang diukur berdasarkan penambahan bobot harian (PBH) ternak sapi bali umur 1,5 tahun yang diberi ransum Hay dan Silase selama satu bulan. Selain itu diamati pula pengaruh dari pemberian ransum pakan dari Hay dan Sialse terhadap performance ternak sapi secara visual terutama kesehatan sapi yang diamati berdasarkan bentuk tubuh, nafsu makan dan minum, bentuk dan tekstur kotorannya, aktivitas dan warna bulu sapi. Secara rinci hasil beberapa paramater yang dijadikan sebagai tolak ukur evaluasi disajikan pada Tabel 3.

Tabel 1. Perubahan status kesuburan tanah, pertumbuhan dan hasil beberapa tanaman tahunan dan semusim sebelum dan setelah penerapan model rancang bangun usahatani ekologis terpadu di desa Akar-akar, Bayan, Lombok Utara

\begin{tabular}{|c|c|c|c|c|}
\hline \multirow[t]{2}{*}{ Variabel Pengamatan } & \multicolumn{2}{|c|}{ Kelompok I di Dusun Batu Keruk } & \multicolumn{2}{|c|}{ Kelompok II di Dusun Batu Kimbung } \\
\hline & Sebelum Aplikasi & Setelah Aplikasi & Sebelum Aplikasi & Setelah Aplikasi \\
\hline
\end{tabular}




\begin{tabular}{|c|c|c|c|c|}
\hline \multicolumn{5}{|l|}{ Status kesuburan tanah } \\
\hline a. pH tanah & 5,70 & 6,20 & 7,70 & 6,40 \\
\hline b. Bahan organik (\%) & 2,20 & 5,85 & 3,20 & 8,05 \\
\hline c. $\mathrm{N}$ total $(\%)$ & 1,01 & 2,78 & 1,38 & 2,42 \\
\hline d. $\mathrm{K}_{2} \mathrm{O} \mathrm{ppm}$ & 2,51 & 3,66 & 2,21 & 3,56 \\
\hline e. $\mathrm{P}_{2} \mathrm{O}_{5} \mathrm{ppm}$ & 3,04 & 4,21 & 3,04 & 5,12 \\
\hline f. KTK (me/100g tanah) & 28,40 & 35,86 & 21,46 & 32,86 \\
\hline g. Indeks populasi cacing & 0,11 & 4,43 & 0,08 & 4,12 \\
\hline \multicolumn{5}{|c|}{ Pertumbuhan tanaman kelapa } \\
\hline a. Jumlah pelepah daun & 8,63 & 12,28 & - & - \\
\hline b. Jumlah tandan buah & 2,61 & 8,34 & - & - \\
\hline c. Luas kanopi $\left(\mathrm{m}^{2}\right)$ & 20,72 & 34,32 & - & - \\
\hline \multicolumn{5}{|c|}{ Pertumbuhan tanaman pisang } \\
\hline a. Jumlah anakan produktif & 1,20 & 3,24 & - & - \\
\hline b. Jumlah pelepah daun & 4,40 & 8,26 & - & - \\
\hline c. Luas kanopi $\left(\mathrm{m}^{2}\right)$ & 12,71 & 28,52 & - & - \\
\hline \multicolumn{5}{|c|}{ Pertumbuhan tanaman mangga } \\
\hline a. Jumlah cabang & - & - & 12,44 & 18,62 \\
\hline b. Tinggi tanaman (m) & - & - & 4,34 & 6,42 \\
\hline c. Luas kanopi $\left(\mathrm{m}^{2}\right)$ & - & - & 8,72 & 14,33 \\
\hline \multicolumn{5}{|c|}{ Pertumbuhan tanaman pepaya } \\
\hline a. Jumlah daun & - & - & 8,33 & 24,62 \\
\hline b. Tinggi tanaman (m) & - & - & 1,82 & 3,62 \\
\hline d. Luas kanopi $\left(\mathrm{m}^{2}\right)$ & - & - & 1,14 & 2,82 \\
\hline \multicolumn{5}{|l|}{ Hasil tanaman tahunan } \\
\hline a. Kelapa selama 6 bulan & 3456 buah/ha & 19.658 buah/ha & - & - \\
\hline b. Pisang selama 6 bulan & 1,422 ton/ha & 2,644 ton/ha & - & - \\
\hline c. Mangga satu musim & - & - & 2,24 ton/ha & 4,84 ton/ha \\
\hline d. Pepaya selama 6 & - & - & 1,48 ton/ha & 2,12 ton/ha \\
\hline \multicolumn{5}{|l|}{ bulan } \\
\hline \multicolumn{5}{|l|}{ Hasil tanaman palawija } \\
\hline a. Jagung & 3,21 ton/ha & 6,78 ton/ha & 3,62 ton.ha & 7,24 ton/ha \\
\hline b. Kacang tanah & 1,71 ton/ha & 3,68 ton/ha & 1,20 ton/ha & 2,84 ton/ha \\
\hline c. Kacang hijau & 0,82 ton/ha & 1,46 ton/ha & 0,76 ton/ha & 1,34 ton/ha \\
\hline \multicolumn{5}{|c|}{ Hasil tanaman sayur-sayuran } \\
\hline a. Kacang panjang & 2,71 ton/ha & 4,83 ton/ha & 2,62 ton/ha & 4,84 ton/ha \\
\hline b. Buncis & 1,82 ton/ha & 3,61 ton/ha & 1,66 ton/ha & 3,12 ton/ha \\
\hline c. Cabe rawit & 2,81 ton/ha & 6,64 ton/ha & 2,66 ton/ha & 6,83 ton/ha \\
\hline d. Cabe merah /besar & 0,92 ton/ha & 1,09 ton/ha & 1,12 ton/ha & 1,44 ton/ha \\
\hline e. Jagung manis & 4,12 ton/ha & 7,84 ton/ha & 3,64 ton/ha & 7,14 ton/ha \\
\hline
\end{tabular}

Tabel 2. Analisis biaya produksi, pendapatan, laba rugi, BC-ratio, BEP, dan efisiensi pengairan (EPA) masing-masing tanaman palawija dan sayur-sayuran yang diusahakan petani mitra di Desa Akar-akar, Bayan Loombok Utara

\begin{tabular}{lllllll}
\hline Tanaman & Biaya & Total & Laba & BC- & \multicolumn{2}{c}{ BEP } \\
\cline { 5 - 6 } yang & Produksi & Pendapatan & $(\mathrm{Rp})$ & Ratio & BEP produksi & BEPharga \\
diusahakan & $(\mathrm{Rp})$ & $(\mathrm{Rp})$ & & & $(\mathrm{kg})$ & (Rp) \\
\hline
\end{tabular}




\begin{tabular}{|c|c|c|c|c|c|c|c|}
\hline \multicolumn{8}{|c|}{ Kelompok I (di Dusun Batu Keruk) } \\
\hline Jagung & $3.550 .000,-$ & 8.790.000,- & 5.240.000,- & $2, .47$ & 4733.33 & 5.071 & 2,53 \\
\hline Kacang tanah & 3.966.000,- & 8.758.000,- & 4.792.000,- & 2,21 & 4957.50 & 9.915 & 2,36 \\
\hline Kacang hijau & $3.895 .000,-$ & $5.250 .7000,-$ & $1.355 .700,-$ & 1,35 & 5193.33 & 15.580 & 1,36 \\
\hline K. panjang & 4.275.500,- & $11,110.000,-$ & 6.834.500,- & 2,60 & 4275.00 & 8.750 & 2,83 \\
\hline Buncis & 4.350.000,- & 11.875.500,- & 7.525.500,- & 2,73 & 4350.00 & 12.000 & 2,76 \\
\hline Cabe rawit & 5.500.000,- & 14.200.000,- & 8.700.000,- & 2,58 & 3667.00 & 12.000 & 2,43 \\
\hline Cabe merah & $6.875 .000,-$ & $7.500 .000,-$ & $625.000,-$ & 1,09 & 3438.00 & 17.050 & 2,01 \\
\hline Jagung manis & 3.765.000,- & $5,890.000,-$ & 2.125.000,- & 1,56 & 5378.60 & 6.845 & 1,14 \\
\hline \multicolumn{8}{|c|}{ Kelompok II (di Dusun Batu Kumbung) } \\
\hline Jagung & 3.575.000,- & 7.895.000,- & 4.320.000,- & 2,21 & 4767.00 & 8.500 & 2,56 \\
\hline Kacang tanah & $3.455 .000,-$ & 9.658.000,- & 6.203.000.- & 2,79 & 3455.00 & & 2,76 \\
\hline
\end{tabular}

9.915

\begin{tabular}{lrrrrrrr}
\hline Kacang hijau & $3.996 .000,-$ & $4.850 .000,-$ & $854.000,-$ & 1,21 & 5328.00 & 15.580 & 1,36 \\
\hline K. panjang & $4.500 .000,-$ & $11.500 .000,-$ & $7.000 .000,-$ & 2,55 & 4500.00 & 9.500 & 2,80 \\
\hline Buncis & $4.275 .500,-$ & $11,110.000,-$ & $6.834 .500,-$ & 2,61 & 4275.00 & 8.750 & 2,83 \\
\hline Cabe rawit & $5.500 .000,-$ & $15.950 .000,-$ & $10.450 .000,-$ & 2,90 & 3143.00 & 11.850 & 3,14 \\
\hline Cabe merah & $6.756 .500,-$ & $7.540 .000,-$ & $783.500,-$ & 1,11 & 3378.00 & 15.580 & 1,36 \\
\hline Jagung manis & $3.265 .000,-$ & $5,000.000,-$ & $1.735 .000,-$ & 1.53 & 4353.00 & 12,345 & 1,12 \\
\hline
\end{tabular}
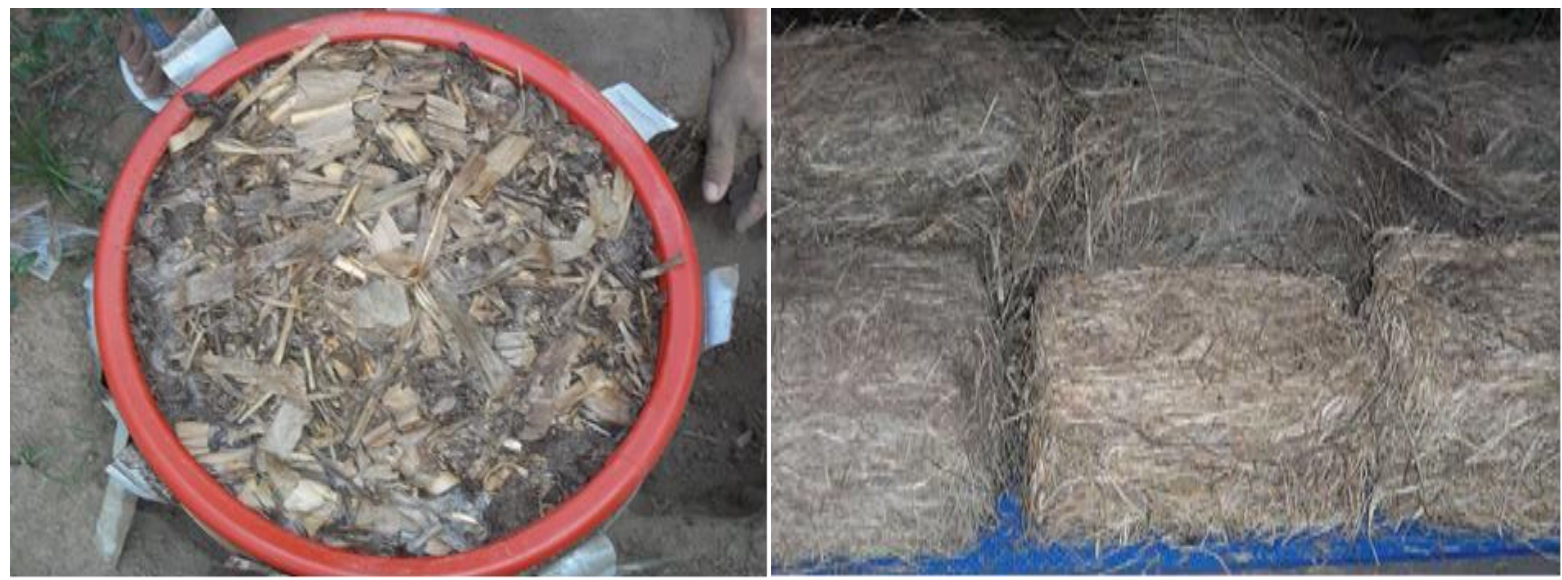

Gambar 4. Pruduk pakan ternak awetan Hay (Gambar kiri) dan Silase (Gambar kanan)

Berdasarkan hasil evaluasi tersebut ternyata secara ekonomi pemanfaatan gulma dan forage sebagai pakan ternak awetan Hay dan Silase mampu memeberikan keuntungan. Pemberian rumput dan forage dalam bentuk segar untuk 2 ekor sapi bali umur 1,5 tahun membutuhkan pakan sebanyak 180 - $200 \mathrm{~kg}$ bahan segar per hari. Namun bila gulma dan forage segar tersebut diolah menjadi Hay dapat memenuhi kebutuhan pakan 2 ekor sapi tersebut untuk 2 hari. Demikian pula bila diolah menjadi silase dengan bahan tambahan limbah pertanian yang tidak dimanfaatkan sebagai pakan dalam bentuk segar maka pemanfaatan pakan akan lebih efisien. Dengan adanya pengolahan dalam bentuk ransum yang ditambah bahan sebagai sumber protein dan lemak seperti dedak, ampas tahu dan limbah pertanian lainnya dengan demikian hasil yang diperoleh tentu lebih tinggi. Pada Tabel 3, tampak jelas bahwa pemberiaan pakan sapi hay dan silase dapat meningkatkan penambahan bobot harian badan sapi bali umur 1,5 tahun 
menjadi $0,720 \mathrm{~kg} / \mathrm{hari}$ untuk pakan hay dan 0,684 $\mathrm{kg} / \mathrm{hari}$ untuk silase. Selain itu performance sapi juga lebih baik dibandingkan bila hanya diberi pakan forage segar saja, terutama nampak dari prilaku sapi sehari-hari lebih lincah dan aktif, sehat dengan kotoran lebih padat serta warna kulit coklat cerah dan mengkilat.

Tabel 3. Perubahan status gizi pakan ternak setelah diolah menjadi foumula Hay dan Silase, serta pengaruhnya terhadap penambahan bobot ternak sapi umur 1,5 tahun.

\begin{tabular}{|c|c|c|c|}
\hline Pengamatan variabel & Pakan segar & Hay & Silase \\
\hline \multicolumn{4}{|l|}{ Status kadar nutrisi pakan (\%) } \\
\hline a. Kadar air & 41,83 & 14,75 & 15,10 \\
\hline b. Kadar abu & 16,72 & 9,10 & 4,65 \\
\hline d. Serat kasar & 34,61 & 24,45 & 27,20 \\
\hline e. Karbohidrat & 22,43 & 45,10 & 56,52 \\
\hline f. Protein & 3,04 & 11,73 & 12,65 \\
\hline g. Lamak & 0,72 & 5.45 & 6,75 \\
\hline TDN (\%) & 81,26 & 95,10 & 94,20 \\
\hline Penambahan bobot sapi & $0,154 \mathrm{~kg} /$ hari & $0,724 \mathrm{~kg} /$ hari & $0,684 \mathrm{~kg} /$ hari \\
\hline \multicolumn{4}{|l|}{ Performance ternak sapi } \\
\hline a. Kesehatan sapi & $\begin{array}{l}\text { Kurang sehat, } \\
\text { Sapi bersendawa } \\
\text { kotoran encer }\end{array}$ & $\begin{array}{l}\text { Sehat dengan } \\
\text { kotoran padat }\end{array}$ & $\begin{array}{l}\text { Sehat dengan kotoran } \\
\text { padat }\end{array}$ \\
\hline b. Aktifitas sapi & $\begin{array}{l}\text { Sapi sering tidur } \\
\text { dan kurang aktif } \\
\text { makan dan } \\
\text { merumput }\end{array}$ & $\begin{array}{l}\text { Sapi lincah dan } \\
\text { begerak aktif }\end{array}$ & $\begin{array}{l}\text { Sapi lincah dan begerak } \\
\text { aktif }\end{array}$ \\
\hline $\begin{array}{l}\text { c. Kenampakan warna bulu } \\
\text { sapi }\end{array}$ & $\begin{array}{l}\text { Coklat kusam dan } \\
\text { kotor }\end{array}$ & $\begin{array}{l}\text { Coklat bersih dan } \\
\text { mengkilat }\end{array}$ & $\begin{array}{l}\text { Coklat bersih dan } \\
\text { mengkilat }\end{array}$ \\
\hline
\end{tabular}

\section{KESIMPULAN DAN SARAN}

\section{Kesimpulan}

1. Pengetahuan dan keterampilan petani dalam mengelola lahan usahataninya semakin meningkat, setelah mengikuti program kegiatan pelatihan dan kaji tindak (demplot).

2. Petani mitra di dusun Batu keruk dan Batu Kumbung desa Akar-akar, Kecamatan Bayan, Kabupaten Lombok Utara, memiliki model produksi berupa sistem usatani ekologis terpadu yang berbasis pada sistem budidaya Allay cropping dengan tanaman pokok kelapa, mangga dan pisang serta tanaman kacang tanah, jagung, kacang panjang, buncis dan cabe rawit sebagai tanaman sisipan.

3. Pengolahan gulma dan forage lainnya menjadi Hay dan Silase dapat memberikan nilai tambah secara ekonomi dan secara agronomis yang menguntungkan karena penggunaan pakan lebih efisien dan gangguan gulma pada tanaman budidaya dapat dikurangi.

\section{Saran}

Disarankan kepada petani mitra di wilayah sasaran untuk terus menerapkan model usahatani ekologis terpadu dengan mengusahakan tanaman jagung, kacang tanah, kacang panjang, buncis dan 
cabe rawit. Hindari mengusahakan tanaman yang membutuhkan pemeliharaan intensif, harga produk tidak stabil dan sulit pemasaran.

\section{UCAPAN TERIMA KASIH}

Terima kasih banyak disampaikan kepada yang terhormat Bapak Rektor Universitas Mataram, Bapak Dekan Fakultas Pertanian Universitas Mataram dan Bapak Ketua LPPM Universitas Mataram atas bantuan dana pengabdian kepada masyarakat PNBP yang telah diberikan. Artikel ini ditulis dari sebagian data yang diperoleh dalam kegiatan pengabdian kepada masyarakat melalui program PPM kemitraan yang didanai dari NPBP Universitas Mataram.

\section{DAFTAR PUSTAKA}

Badan Pusat Statistik, NTB., 2001. Data Pokok Pembangunan Propinsi Nusa Tenggara Barat. Kerjasama Bappeda Tk. I NTB dengan Kantor Wilayah Badan Pusat Statistik (BPS) Propinsi NTB.

Dickey, E.C. 1984 . Tillage and erosion in a wheat-fallow rotation pp. 183-195. In Proc. Of Great Plants Concervation Tillage Symphosium. North Plate, N.P. 2123 August. USA.

Ernawati NML \& Ngawit | Ketut, 2015. Eksplorasi dan identifikasi gulma hijauan pakan dan limbah pertanian yang dimanfaatkan sebagai pakan ternak di wilayah lahan kering Lombok Utara. Buletin Peternakan (Bulletin of Animal Science), $\quad 39 \quad$ (2) : 92-102. http://buletinpeternakan.fapet.ugm.ac.i d/

Ernawati NML, Ngawit I Ketut, and Nihla Farida, 2014. Effectiveness of organic wates and forages to increase soil fertility status and crop yield id dry lands. Journal of Degraded and Mining Lands Management, 1(4) : 165-174. http://jdmlm.ub.ac.id
Hutwan S., W. A. Sumadja, Hamzah, E. Kartika, Adriani dan J.Andayani, 2016.Pengenalan Teknik Usahatani Terpadu di Kawasan Ekonomi Masyarakat Desa Pudak. Jurnal Pengabdian Kepada Masyarakat.(31) 4 : 1-4.

Kusnarta, I.G.M., 1996. Evapotranspirasi dan Hasil Tanaman Jagung pada Berbagai Dosis Pupuk Kandang dan Mulsa. Agroteksos, Journal Fakultas Pertanian Universitas Mataram, Vol 6 (3) : 152 158.

Kusnarta, I.G.M., H.M. Tarudi, I.P., Silawibawa, dan M. Husni Idris, 1998. Kajian Usahatani Konservasi dengan Budidaya Lorong Menggunakan Tanaman Buah Serikaya (Annona squamosa L.) dan Legum. Laporan Hasil Penelitian Dosen Muda. Fakultas Pertanian Universitas Mataram.

Ngawit I Ketut, Ekaputra Gunartha I Gde dan Nihla Farida, 2018. Potensi Gulma dan Hijauan Lainnya pada Tanah Bawah Naungan Kelapa yang Dimanfaakan Sebagai Pakan Ternak di Wilayah Lahan Kering Lombok Utara. Prosiding Seminar Nasional, Implementasi IPTEK Pertanian Berkelanjutan yang Tangguh Menuju Kedaulatan Pangan. Fakultas PertanianUniversitas Mataram. Mataram. Hal. 290-304.

Ngawit, I Ketut dan Nihla Farida, 1999. Efek Pemberian Pupuk Kandang dan Kalium Secara Bertahap terhadap Pertumbuhan danHasil Kedelai di Lahan Kering Wilayah Pengembangan Lombok Utara. Makalah Seminar Hasil Penelitian Proyek Pengembangan Sebelas Lembaga Pendidikan Tinggi (P2SLPT), Ditjen Dikti, di Universitas Mataram.

Ngawit, I Ketut, 2002. Optimalisasi Penerapan Teknologi Budidaya Lorong (Allay Croping) antara Tanaman Buah-Buahan 
Tahunan dengan Beberapa Jenis Tanaman Sayur-sayuran semusim di Wilayah Pengembangan Lahan Kering Kecamatan Bayan Kabupaten Lombok Barat NTB. Makalah Seminar Program Pengembangan Budaya Kewirausahaan di PT, DP3M, Direktorat Jenderal Pendidikan Tinggi, Jakarta.

Ngawit, I Ketut, IG. M. Kusnarta, Agus Rohyadi dan Wuryantoro, 2008. Rancang Bangun
Usahatani Ekologis Terpadu yang Bertumpu pada Pengelolaan Sumber Daya Lahan Berkelanjutan pada Tiga Tipe Agroekosistem Lahan kering di Pulau Lombok. Laporan Hasil Penelitian Hibah Bersaing 2007-2008, Direktorat Jenderal Pendidikan Tinggi, Departemen Pendidikan Nasional, Jakarta. 